\title{
Determinant Factors of Working Children based on Conditional Logistics Regression for Matched Pairs Data*
}

\author{
Determinan Anak Bekerja Berdasarkan Model Regresi Logistik \\ Bersyarat untuk Data Berpasangan
}

\section{Rizky Zulkarnain ${ }^{1 \ddagger}$, Tri Listianingrum², and Khairil Anwar Notodiputro $^{3}$}

\author{
1,2Badan Pusat Statistik, Indonesia \\ ${ }^{3}$ Department of Statistics, IPB University, Indonesia \\ ‡corresponding author: zulqarnaen@bps.go.id
}

Copyright @ 2021 Rizky Zulkarnain, Tri Listianingrum, and Khairil Anwar Notodiputro. This is an openaccess article distributed under the Creative Commons Attribution License, which permits unrestricted use, distribution, and reproduction in any medium, provided the original work is properly cited.

\begin{abstract}
Working children may create problem since it relates to human right as well as to the development of children especially in getting sufficient education. This paper discusses determinant factors of working children by using conditional logistics regression for matched pairs data. Matching is employed to adjust confounding factors and to avoid bias. In this paper there are three confounding factors that have been considered, i.e. residential area, gender, and income of household head. The results showed that the conditional regression model outperformed the standard regression model. The number of household members, whether the head of household was married or single, age of the head of household, educational attainment of the head of household, as well as the work status of the head of household were the determinant factors of the working children.
\end{abstract}

Keywords: bias, case-control, conditional maximum likelihood, confounding, observational study.

\footnotetext{
${ }^{*}$ Received: Des 2020; Reviewed: Jan 2021; Published: Mar 2021
} 


\section{Pendahuluan}

Masa kecil anak tidak seharusnya dihabiskan dengan bekerja. Negara mengatur masalah pekerja anak, dimana UU No. 13 (2003) menetapkan bahwa "...pengusaha dilarang mempekerjakan anak...dikecualikan bagi anak yang berumur antara 13 (tiga belas) tahun sampai dengan 15 (lima belas) tahun untuk melakukan pekerjaan ringan sepanjang tidak mengganggu perkembangan dan kesehatan fisik, mental, dan sosial...". Hal ini diperkuat oleh UU No. 20 (2003) yang menyatakan “...setiap warga negara yang berusia tujuh sampai dengan lima belas tahun wajib mengikuti pendidikan dasar...".

Pekerja anak adalah "anak yang terlibat dalam pekerjaan yang merampas masa kanak-kanak, potensi, dan martabat seorang anak, dan yang berbahaya bagi perkembangan fisik dan mentalnya" (UNICEF, 2020). Menurut hasil Sakernas 2018, masih terdapat $8.49 \%$ anak bekerja di Indonesia. Padahal, pemerintah menargetkan bahwa pada tahun 2022 Indonesia telah bebas dari pekerja anak (Kemenaker, 2014).

Keberadaan pekerja anak melanggar hak asasi manusia dan mengganggu perkembangan serta kesempatannya untuk memperoleh pendidikan yang baik. Thapa et al. (1996) mengatakan bahwa "membiarkan anak bekerja sebagai pengganti bersekolah dapat membuat lingkaran setan (vicious cycle): awalnya, bekerja menimbulkan dampak buruk bagi sekolah, selanjutnya berpendidikan rendah atau tidak berpendidikan sama sekali dapat mengakibatkan berlanjutnya pekerja anak". Usman (2002) juga menegaskan bahwa anak dari keluarga miskin yang bekerja pada usia dini akan melestarikan kemiskinan.

Cita-cita mewujudkan Indonesia bebas dari pekerja anak memerlukan langkah konkrit melalui pengendalian faktor-faktor yang mempengaruhi adanya pekerja anak baik dari sisi supply maupun demand. Pada sisi demand, pemerintah dapat membuat perangkat hukum yang sedemikian rupa sehingga tidak ada perusahaan yang dapat mempekerjakan anak. Namun tampaknya hal tersebut belum dilakukan dengan efektif melihat masih banyaknya pekerja anak di Indonesia. Pada sisi supply, fenomena pekerja anak dapat disebabkan oleh banyak faktor (demografi, ekonomi dan sosial). Makalah ini membahas isu faktor apa saja yang berpengaruh terhadap kecenderungan anak bekerja dengan menggunakan model dan analisis statistika. Hasilnya dapat digunakan untuk merumuskan skala prioritas kebijakan dan intervensi yang perlu diambil untuk dapat mengentaskan pekerja anak secara efektif.

Penelitian tentang determinan anak bekerja di Indonesia telah banyak dilakukan, misalnya oleh Priyambada et al. (2005), Iryani dan Priyarsono (2013), Ikawati (2015), Haszelinna dan Arabsheibani (2016), serta Utama dan Handayani (2020). Namun, penelitian-penelitian ini umumnya belum menggunakan analisis data berpadanan. Padahal, analisis data berpadanan berguna untuk menyesuaikan efek pembaur (confounder) dan menghindari bias (Kuo et al., 2018). Hal ini bisa dimaklumi karena analisis data berpadanan memerlukan teknik statistika yang lebih lanjut menggunakan model regresi logistik bersyarat.

Makalah ini bertujuan untuk menganalisis faktor determinan anak bekerja dengan menggunakan teknik pemadanan (matching) dan model regresi logistik bersyarat. Terdapat tiga peubah pembaur yang dipertimbangkan dalam pemadanan, yaitu daerah tempat tinggal, jenis kelamin anak, dan pendapatan kepala rumah tangga (KRT). Secara spesifik, studi ini mempunyai dua tujuan. Tujuan pertama adalah 
membandingkan hasil analisis sebelum pemadanan (menggunakan regresi logistik baku) dan analisis setelah pemadanan (menggunakan regresi logistik bersyarat). Tujuan kedua adalah mengukur pengaruh dari setiap peubah penjelas terhadap status anak bekerja.

\section{Metodologi}

\subsection{Bahan dan Data}

Studi ini menggunakan data Survei Angkatan Kerja Nasional (Sakernas) bulan Agustus 2018, yang dikompilasi oleh Badan Pusat Statistik (BPS). Sakernas Agustus 2018 dirancang untuk menyajikan statistik hingga level kabupaten/kota, menggunakan teknik percontohan two stages one phase stratified sampling. Unit analisis dalam studi ini adalah anak berusia 10-17 tahun. Jumlah data adalah sebanyak 111528 amatan. Studi ini menggunakan tiga peubah pembaur (confounder) dan enam peubah penjelas. Peubah pembaur digunakan dalam proses pemadanan data. Daftar peubah yang digunakan dapat dilihat pada Tabel 1.

Tabel 1: Daftar peubah yang digunakan dalam analisis.

\begin{tabular}{cclll} 
No. & Peubah & \multicolumn{1}{c}{ Deskripsi } & \multicolumn{1}{c}{ Keterangan } \\
\hline 1 & $\mathrm{Y}$ & Status anak bekerja & 1 & Bekerja \\
& & & 2 & Tidak bekerja \\
2 & $\mathrm{C}_{1}$ & Peubah pembaur 1: daerah tempat tinggal & 1 & Perkotaan \\
& & & 2 & Perdesaan \\
3 & $\mathrm{C}_{2}$ & Peubah pembaur 2: jenis kelamin anak & 1 & Laki-laki \\
& & & 2 & Perempuan \\
4 & $\mathrm{C}_{3}$ & Peubah pembaur 3: pendapatan KRT & 1 & $<=$ Median \\
& & & 2 & $>$ Median \\
5 & $\mathrm{X}_{1}$ & Jumlah ART & Numerik \\
6 & $\mathrm{X}_{2}$ & Jenis kelamin KRT & 1 & Laki-laki \\
& & & 2 & Perempuan \\
7 & $\mathrm{X}_{3}$ & Umur KRT & Numerik \\
8 & $\mathrm{X}_{4}$ & Status kawin KRT & 1 & Kawin \\
& & & 2 & Tidak kawin \\
9 & $\mathrm{X}_{5}$ & Pendidikan tertinggi yang ditamatkan KRT & 1 & Tidak pernah \\
& & & 2 sekolah/tidak tamat SD \\
& & & 2 & SD/sederajat \\
& & & 3 & SMP/sederajat \\
& & & 4 & SMA/sederajat \\
10 & $\mathrm{X}_{6}$ & Status pekerjaan KRT & 5 & Perguruan Tinggi \\
& & & 1 & Tidak bekerja/Pekerja \\
& & & 2 & informal \\
& & & & Pekerja formal \\
& &
\end{tabular}

Sesuai dengan definisi BPS, bekerja merupakan "kegiatan ekonomi yang dilakukan oleh seseorang dengan maksud memperoleh atau membantu memperoleh pendapatan atau keuntungan, paling sedikit satu jam (tidak terputus) dalam seminggu yang lalu" (BPS, 2017). Pekerja informal mencakup pekerja yang berusaha/bekerja sendiri, pekerja yang berusaha/bekerja dibantu buruh/pekerja tidak tetap/pekerja tak dibayar, pekerja lepas, dan pekerja tidak dibayar. Sedangkan, pekerja formal mencakup pekerja yang berusaha dengan dibantu pekerja/buruh tetap dan buruh/karyawan/pekerja dibayar. 


\subsection{Analisis Regresi Logistik}

Peubah respon status anak bekerja bersifat biner, sehingga model regresi logistik dapat digunakan sebagai berikut (Agresti, 2007; Azen dan Walker, 2011):

$$
\ln \left(\frac{\pi(\boldsymbol{x})}{1-\pi(\boldsymbol{x})}\right)=\beta_{0}+\beta_{1} x_{1}+\beta_{2} D_{2}+\beta_{3} x_{3}+\beta_{4} D_{4}+\sum_{j=1}^{4} \beta_{5 j} D_{5 j}+\beta_{6} D_{6}
$$

dengan: $\pi(\boldsymbol{x})$ : peluang anak bekerja

$x_{1}$ : jumlah anggota rumah tangga (ART)

$D_{2}= \begin{cases}1, & \text { jika jenis kelamin KRT laki-laki } \\ 0, & \text { jika jenis kelamin KRT perempuan }\end{cases}$

$x_{3}$ : umur kepala rumah tangga (KRT)

$D_{4}= \begin{cases}1, & \text { jika KRT berstatus kawin } \\ 0, & \text { jika KRT berstatus tidak kawin }\end{cases}$

$D_{51}= \begin{cases}1, & \text { jika KRT tamat SD/sederajat } \\ 0, & \text { jika KRT tidak pernah sekolah/tidak tamat SD }\end{cases}$

$D_{52}= \begin{cases}1, & \text { jika KRT tamat SMP/sederajat } \\ 0, & \text { jika KRT tidak pernah sekolah/tidak tamat SD }\end{cases}$

$D_{53}= \begin{cases}1, & \text { jika KRT tamat SMA/sederajat } \\ 0, & \text { jika KRT tidak pernah sekolah/tidak tamat SD }\end{cases}$

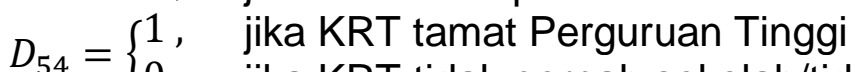

$D_{54}= \begin{cases}0, & \text { jika KRT tidak pernah sekolah/tidak tamat SD }\end{cases}$

$D_{6}= \begin{cases}1, & \text { jika KRT tidak bekerja/pekerja informal } \\ 0, & \text { jika KRT pekerja formal }\end{cases}$

Sudah umum diketahui (James et al., 2013) bahwa dari persamaan (1) jika peubah lain tetap, maka peningkatan $x_{i}$ sebesar satu unit akan meningkatkan log-odds. Jika $\beta_{i}$ positif, maka peningkatan $x_{i}$ akan meningkatkan $\pi(\boldsymbol{x})$, sedangkan jika $\beta_{i}$ negatif, maka peningkatan $x_{i}$ menurunkan $\pi(\boldsymbol{x})$. Dugaan parameter $\boldsymbol{\beta}=\left(\beta_{0}, \ldots, \beta_{k}\right)$ dapat diperoleh dengan metode kemungkinan maksimum. Solusi dari fungsi log-likelihood dapat diperoleh dengan metode iterasi seperti Newton-Raphson ataupun Fisher scoring. Untuk mengetahui pengaruh dari peubah penjelas terhadap respon dapat digunakan Deviance sebagai berikut:

$$
\begin{gathered}
\text { Deviance }=-2\left[L_{\text {Reduced }}-L_{\text {Saturated }}\right] \\
\Delta \text { Deviance }=\text { Deviance }\left(H_{0}\right)-\text { Deviance }\left(H_{1}\right)
\end{gathered}
$$

Suatu peubah penjelas dikatakan berpengaruh terhadap respon jika nilai $\Delta$ Deviance lebih besar daripada nilai chi-square $\chi_{\alpha(\Delta d b)}^{2}$, dimana $\Delta d b$ adalah selisih antara derajat bebas dalam hipotesis nol $\left(H_{0}\right)$ dengan derajat bebas dalam hipotesis alternatif $\left(H_{1}\right)$ dan $\alpha$ adalah besarnya taraf nyata yang ditentukan.

\subsection{Analisis Regresi Logistik Bersyarat}

Misalkan $\left(Y_{i 1}, Y_{i 2}\right)$ adalah pasangan ke- $i$ dari observasi, maka model bersyaratnya adalah sebagai berikut (Agresti, 2002):

$$
\operatorname{logit}\left[P\left(Y_{i t}=1\right)\right]=\beta_{0 i}+\sum_{j=1}^{k} \beta_{j} x_{i j t} ; t=1,2
$$


Misalkan $S_{i}=y_{i 1}+y_{i 2}$ adalah statistik cukup yang merupakan total "sukses" dari setiap pasangan, $\boldsymbol{x}_{i t}=\left(x_{1 i t}, \ldots, x_{k i t}\right)^{\prime}$ adalah vektor peubah penjelas untuk pasangan ke- $i$ dan amatan ke- $t$, dan $\beta=\left(\beta_{1}, \ldots, \beta_{k}\right)^{\prime}$ adalah vektor parameter, maka:

$$
\begin{aligned}
P\left(Y_{i 1}=0, Y_{i 2}=1 \mid S_{i}=1\right) & =\frac{\exp \left(\boldsymbol{x}_{i 2}^{\prime} \boldsymbol{\beta}\right)}{\exp \left(\boldsymbol{x}_{i 1}^{\prime} \boldsymbol{\beta}\right)+\exp \left(\boldsymbol{x}_{i 2}^{\prime} \boldsymbol{\beta}\right)} \\
& =\frac{\exp \left\{\left(\boldsymbol{x}_{i 2}^{\prime}-\boldsymbol{x}_{i 1}^{\prime}\right) \boldsymbol{\beta}\right\}}{1+\exp \left\{\left(\boldsymbol{x}_{i 2}^{\prime}-\boldsymbol{x}_{i 1}^{\prime}\right) \boldsymbol{\beta}\right\}} \\
P\left(Y_{i 1}=1, Y_{i 2}=0 \mid S_{i}=1\right) & =\frac{\exp \left(\boldsymbol{x}_{i 1}^{\prime} \boldsymbol{\beta}\right)}{\exp \left(\boldsymbol{x}_{i 1}^{\prime} \boldsymbol{\beta}\right)+\exp \left(\boldsymbol{x}_{i 2}^{\prime} \boldsymbol{\beta}\right)} \\
& =\frac{1}{1+\exp \left\{\left(\boldsymbol{x}_{i 2}^{\prime}-\boldsymbol{x}_{i 1}^{\prime}\right) \boldsymbol{\beta}\right\}}
\end{aligned}
$$

Persamaan (2) identik dengan peluang "sukses" pada persamaan regresi logistik baku tanpa intercept, dimana peubah penjelas diganti dengan $\boldsymbol{x}_{i}^{*}=\boldsymbol{x}_{i 2}-\boldsymbol{x}_{i 1}$ dan kejadian "sukses" $y^{*}=1$ didefinisikan sebagai $\left(y_{i 1}=0, y_{i 2}=1\right)$. Sedangkan, persamaan (3) identik dengan peluang "gagal" yang bersesuaian, dimana peubah penjelas diganti dengan $\boldsymbol{x}_{i}^{*}=\boldsymbol{x}_{i 2}-\boldsymbol{x}_{i 1}$ dan kejadian "gagal" $\boldsymbol{y}^{*}=0$ didefinisikan sebagai $\left(y_{i 1}=1, y_{i 2}=0\right)$. Dengan demikian, penduga kemungkinan maksimum pada regresi logistik bersyarat dapat dihitung dengan cara yang serupa seperti regresi logistik baku, dengan cara mengganti peubah penjelas dengan $\boldsymbol{x}_{i}^{*}$ dan peubah respon dengan $y^{*}$, serta mengeluarkan intercept dari model (Hosmer dan Lemeshow, 2000). Makalah ini menggunakan fungsi "clogit" dalam package "survival" pada software R untuk mendapatkan dugaan parameter regresi logistik bersyarat.

\subsection{Pemadanan Data (Matching)}

Penelitian ini menggunakan teknik pemadanan (matching) untuk mengeliminasi bias. Data dipadankan berdasarkan kesamaan peubah pembaur (daerah tempat tinggal, jenis kelamin anak dan pendapatan KRT). Dengan kata lain, proses pemadanan telah mempertimbangkan pengaruh dari peubah pembaur. Langkah-langkah yang dilakukan adalah sebagai berikut:

a. Membagi data menjadi data case (anak bekerja) dan data control (anak tidak bekerja).

b. Melakukan pengacakan pada subset data control.

c. Memadankan setiap amatan di data case, yaitu yang memiliki peubah pembaur (daerah tempat tinggal, jenis kelamin anak, dan pendapatan KRT) yang sama dengan data control yang telah teracak.

d. Memberikan ld untuk setiap pasangan dan menyusun data berdasarkan pasangannya masing-masing, seperti disajikan dalam Tabel 2.

Data yang telah dipadankan dianalisis menggunakan regresi logistik bersyarat. Hasilnya kemudian dibandingkan dengan regresi logistik baku yang menggunakan data yang belum dipadankan. Kinerja masing-masing model dievaluasi menggunakan Residual Deviance dan Akaike Information Criterion (AIC).

$$
A I C=2 p-2 \ln (\widehat{L})
$$

dengan $p$ adalah banyaknya parameter di dalam model dan $\hat{L}$ adalah nilai maksimum dari fungsi likelihood model. 
Tabel 2: Contoh hasil padanan untuk 5 pasangan amatan.

\begin{tabular}{ccccccccccc}
\hline Id_Pasangan & C1 & C2 & C3 & Y & X1 & X2 & X3 & X4 & X5 & X6 \\
\hline 1 & 1 & 1 & 1 & 1 & 5 & 1 & 38 & 1 & 4 & 1 \\
1 & 1 & 1 & 1 & 2 & 3 & 1 & 46 & 1 & 1 & 1 \\
2 & 1 & 2 & 1 & 1 & 2 & 1 & 54 & 2 & 2 & 1 \\
2 & 1 & 2 & 1 & 2 & 5 & 2 & 60 & 1 & 4 & 2 \\
3 & 2 & 1 & 1 & 1 & 5 & 1 & 44 & 1 & 3 & 2 \\
3 & 2 & 1 & 1 & 2 & 3 & 2 & 52 & 1 & 2 & 1 \\
4 & 2 & 1 & 2 & 1 & 4 & 2 & 38 & 2 & 2 & 1 \\
4 & 2 & 1 & 2 & 2 & 10 & 2 & 61 & 2 & 2 & 1 \\
5 & 2 & 2 & 1 & 1 & 9 & 2 & 48 & 1 & 1 & 1 \\
5 & 2 & 2 & 1 & 2 & 2 & 1 & 41 & 2 & 2 & 1 \\
\hline
\end{tabular}

\section{Hasil dan Pembahasan}

\subsection{Gambaran Umum Anak Bekerja di Indonesia}

Berdasarkan hasil Sakernas 2018, prevalensi anak usia 10-17 tahun yang bekerja cukup besar, yaitu sebesar $8.49 \%$. Kemudian, terdapat $91.51 \%$ anak yang tidak bekerja (Gambar 1). Pada Gambar 2 disajikan persentase anak bekerja menurut lapangan usaha. Anak ini umumnya bekerja di sektor Pertanian (51.35\%), Perdagangan (22.86\%), Industri Pengolahan (9.31\%), serta Hotel dan Restoran (6.70\%). Dengan demikian, sekitar $90.22 \%$ anak bekerja di keempat sektor ini. Sisanya tersebar di sektor Jasa-jasa (2.72\%), Konstruksi (2.46\%), Pertambangan (1.71\%), Transportasi (1.30\%), dan lain sebagainya.

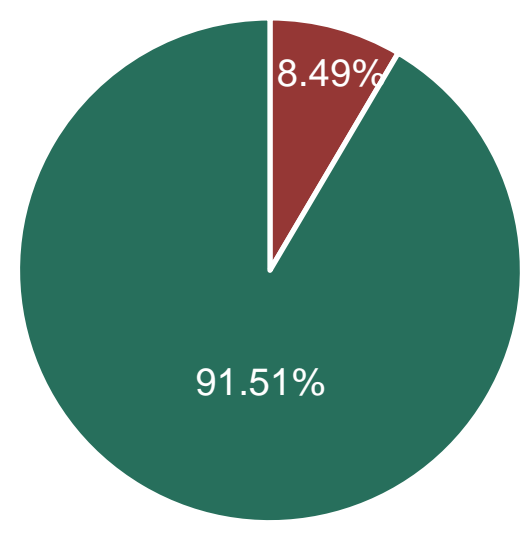

- Anak bekerja

- Anak tidak bekerja

Gambar 2: Persentase anak 10-17 tahun menurut status bekerja.

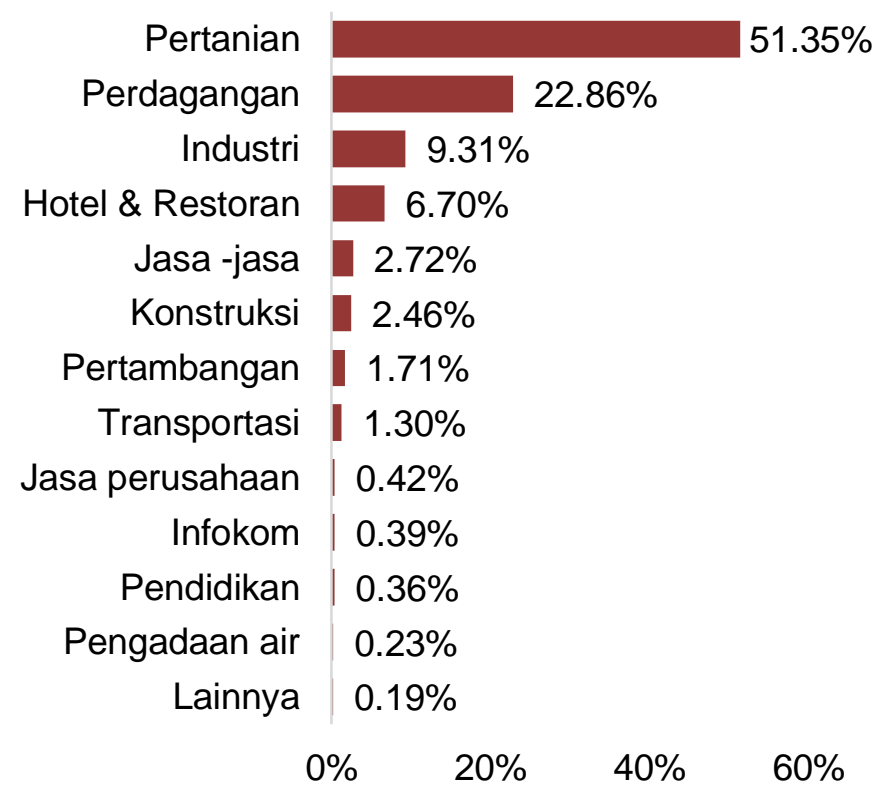

Gambar 1: Persentase anak bekerja menurut lapangan usaha.

Kondisi pendidikan tertinggi yang ditamatkan KRT disajikan pada Gambar 3. Persentasenya cukup merata, dengan KRT tamat SD/sederajat dan tamat SMA/sederajat masing-masing sebesar $28.22 \%$ dan $25.69 \%$. Kemudian terdapat $19.59 \%$ KRT yang tidak pernah sekolah/tidak tamat SD, $17.43 \%$ yang tamat SMP/sederajat, dan $9.06 \%$ yang tamat Perguruan Tinggi. Gambar 4 menunjukkan 
bahwa persentase anak yang bekerja cenderung menurun ketika pendidikan KRT semakin tinggi. KRT yang tidak pernah sekolah/tidak tamat SD memiliki persentase anak bekerja paling besar, yaitu sebesar $13.12 \%$. Persentase anak bekerja kemudian menurun menjadi $9.20 \%$ jika KRT tamat SD/sederajat, $7.81 \%$ jika KRT tamat SMP/sederajat, dan $6.44 \%$ jika KRT tamat SMA/sederajat. KRT yang berpendidikan tamat Perguruan Tinggi memiliki persentase anak bekerja paling kecil, yaitu sebesar $3.35 \%$.

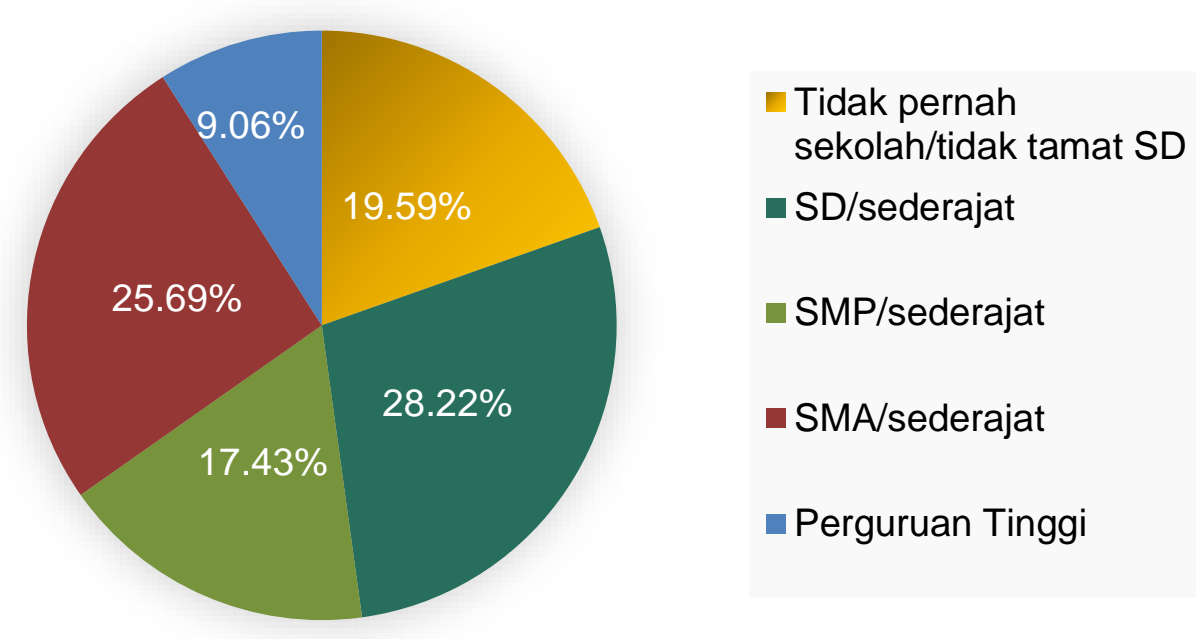

Gambar 3: Tingkat pendidikan KRT.

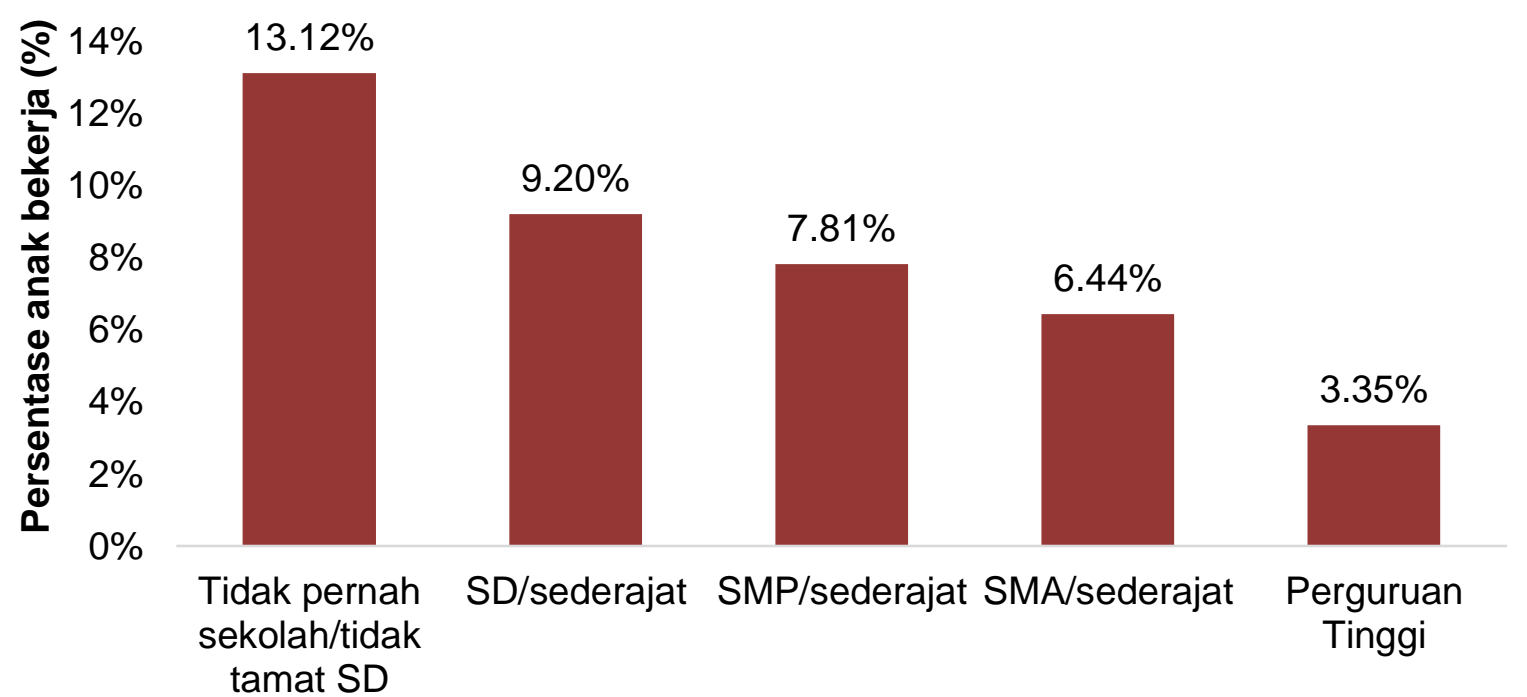

\section{Pendidikan KRT}

Gambar 4: Persentase anak bekerja menurut tingkat pendidikan KRT.

Gambar 5 menampilkan distribusi status pekerjaan KRT. Sekitar $65.36 \%$ KRT berstatus tidak bekerja/pekerja informal. Sisanya sebesar 34.64\% KRT berstatus sebagai pekerja formal. Persentase anak bekerja menurut status pekerjaan KRT disajikan dalam Gambar 6. Anak dengan KRT yang berstatus tidak bekerja/pekerja informal memiliki peluang yang lebih besar untuk bekerja dibandingkan anak yang 
KRT-nya berstatus pekerja formal. Persentase anak bekerja pada KRT dengan status tidak bekerja/pekerja informal adalah sebesar $10.14 \%$, sedangkan persentase anak bekerja pada KRT dengan status pekerja formal adalah sebesar $5.37 \%$.

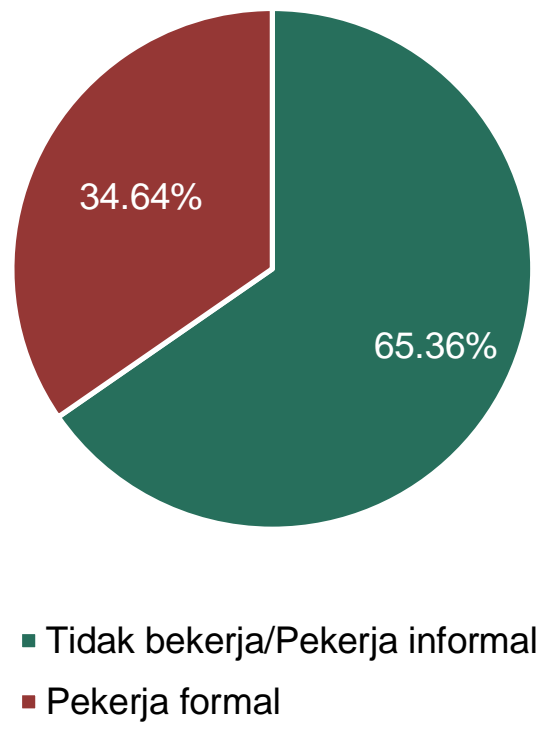

Gambar 5: Status pekerjaan.KRT.

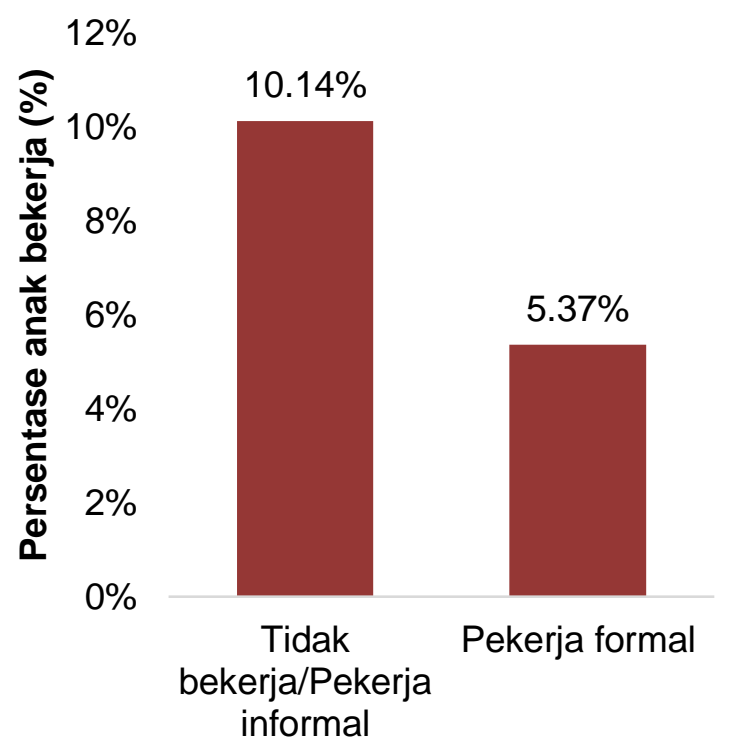

Status pekerjaan KRT

Gambar 6: Persentase anak bekerja menurut status pekerjaan KRT.

\subsection{Analisis Sebelum Pemadanan}

Model regresi logistik baku diterapkan pada data sebelum dilakukan pemadanan. Dengan kata lain, efek peubah pembaur belum dipertimbangkan. Hasil pengujian pengaruh peubah penjelas disajikan pada Tabel 3. Tampak bahwa seluruh peubah penjelas berpengaruh nyata terhadap status anak bekerja. Nilai- $p$ dari setiap peubah tersebut sangat kecil.

Tabel 3: Hasil uji signifikansi peubah penjelas (sebelum pemadanan)

\begin{tabular}{lccc}
\hline \multicolumn{1}{c}{ Peubah } & $\begin{array}{c}\text { Derajat } \\
\text { bebas }\end{array}$ & Chi-square & Nilai-p \\
\hline X $_{1}$ (Jumlah ART) & 1 & 47.48 & 0.000 \\
X $_{2}$ (Jenis kelamin KRT) & 1 & 7.11 & 0.008 \\
X $_{3}$ (Umur KRT) & 1 & 47.22 & 0.000 \\
X $_{4}$ (Status kawin KRT) & 1 & 11.19 & 0.001 \\
X $_{5}$ (Pendidikan KRT) & 4 & 651.29 & 0.000 \\
X $_{6}$ (Status pekerjaan KRT) & 1 & 301.45 & 0.000 \\
\hline Keterangan: nyata pada taraf 5\% & & &
\end{tabular}

Dugaan koefisien dan odds ratio untuk setiap peubah penjelas beserta kategorinya disajikan dalam Tabel 4. Jumlah ART sebagai representasi dari jumlah tanggungan berasosiasi positif dengan status anak bekerja. Semakin banyak jumlah ART, semakin besar pula risiko anak untuk bekerja. Jika jumlah ART bertambah sebanyak 1 orang, maka risiko anak untuk bekerja meningkat sebesar $4.5 \%$ dibanding sebelumnya. KRT laki-laki memiliki risiko yang lebih rendah dibandingkan KRT perempuan untuk 
memiliki anak yang bekerja, yaitu sebesar 0.873 kali. Selanjutnya, hasil regresi logistik menunjukkan bahwa umur KRT berasosiasi negatif dengan peluang anak bekerja. Semakin bertambah umur KRT, semakin kecil peluang anak untuk bekerja. Pertambahan umur KRT 1 tahun, menurunkan risiko anak untuk bekerja sebesar $0.8 \%$.

Tabel 4: Dugaan koefisien dan Odds Ratio untuk setiap peubah penjelas dan kategorinya (sebelum pemadanan)

\begin{tabular}{|c|c|c|c|c|}
\hline Peubah & Koefisien & $\begin{array}{l}\text { Galat } \\
\text { baku }\end{array}$ & $\begin{array}{l}\text { Odds } \\
\text { Ratio }\end{array}$ & $\begin{array}{c}\text { Selang } \\
\text { kepercayaan 95\% } \\
\text { bagi Odds Ratio }\end{array}$ \\
\hline Konstanta & -1.883 & 0.076 & 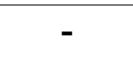 & - \\
\hline $\begin{array}{l}\text { Jumlah ART } \\
\text { Jenis kelamin KRT: }\end{array}$ & 0.044 & 0.006 & 1.045 & $(1.032 ; 1.058)$ \\
\hline Laki-laki & -0.136 & 0.051 & 0.873 & $(0.790 ; 0.964)$ \\
\hline Umur KRT & -0.008 & 0.001 & 0.992 & $(0.990 ; 0.994)$ \\
\hline $\begin{array}{l}\text { Status kawin KRT: } \\
\text { Kawin }\end{array}$ & -0.166 & 0.049 & 0.847 & $(0.769 ; 0.933)$ \\
\hline Pendidikan KRT: & & & & \\
\hline SD/sederajat & -0.363 & 0.028 & 0.696 & $(0.658 ; 0.736)$ \\
\hline SMP/sederajat & -0.522 & 0.034 & 0.593 & $(0.555 ; 0.634)$ \\
\hline SMA/sederajat & -0.641 & 0.033 & 0.527 & $(0.494 ; 0.562)$ \\
\hline Perguruan Tinggi & -1.179 & 0.061 & 0.308 & $(0.273 ; 0.347)$ \\
\hline Status pekerjaan KRT: & & & & \\
\hline $\begin{array}{l}\text { Tidak bekerja/Pekerja } \\
\text { informal }\end{array}$ & 0.464 & 0.028 & 1.591 & $(1.507 ; 1.679)$ \\
\hline
\end{tabular}

KRT yang berstatus kawin memiliki risiko yang lebih rendah untuk menghasilkan anak bekerja, yaitu 0.847 kali dibandingkan dengan KRT yang berstatus tidak kawin. Hal yang menarik adalah risiko anak bekerja menurun secara teratur seiring dengan meningkatnya pendidikan KRT. Anak dengan KRT yang berpendidikan tamat $\mathrm{SD} /$ sederajat memiliki risiko yang lebih rendah (0.696 kali) untuk bekerja dibandingkan anak dengan KRT yang tidak pernah sekolah/tidak tamat SD. Risiko ini kemudian menurun menjadi 0.593 kali dan 0.527 kali jika KRT berpendidikan tamat SMP/sederajat atau tamat SMA/sederajat. Anak dengan KRT berpendidikan tamat Perguruan Tinggi memiliki risiko paling rendah untuk bekerja, yaitu sebesar 0.308 kali dibandingkan anak dengan KRT yang tidak pernah sekolah/tidak tamat SD. Peubah terakhir yang berpengaruh terhadap status anak bekerja adalah status pekerjaan KRT. Anak dengan KRT berstatus tidak bekerja/pekerja informal memiliki risiko lebih tinggi (1.591 kali) untuk bekerja dibandingkan anak dengan KRT berstatus pekerja formal.

Persamaan yang dihasilkan adalah sebagai berikut:

$$
\begin{gathered}
\ln \left(\frac{\hat{\pi}}{1-\hat{\pi}}\right)=-1.883+0.044 x_{1}-0.136 D_{2}-0.008 x_{3}-0.166 D_{4}-0.363 D_{51}-0.522 D_{52} \\
-0.641 D_{53}-1.179 D_{54}+0.464 D_{6}
\end{gathered}
$$

\subsection{Analisis Setelah Pemadanan}

Hasil pemadanan menyebabkan peubah jenis kelamin KRT tidak nyata terhadap status anak bekerja dengan nilai- $p$ sebesar 0.280. Dengan demikian, jika efek pembaur 
telah dipertimbangkan, kesimpulan yang dihasilkan bisa menjadi berbeda. Sementara itu, peubah penjelas lainnya tetap berpengaruh nyata terhadap status anak bekerja dengan nilai- $p$ seperti pada Tabel 5.

Tabel 5: Hasil uji peubah penjelas (setelah pemadanan)

\begin{tabular}{lccc}
\hline \multicolumn{1}{c}{ Peubah } & $\begin{array}{c}\text { Derajat } \\
\text { bebas }\end{array}$ & Chi-square & Nilai- $p$ \\
\hline X $_{1}$ (Jumlah ART) & 1 & 25.020 & 0.000 \\
X $_{2}$ (Jenis kelamin KRT) & 1 & 1.166 & 0.280 \\
X $_{3}$ (Umur KRT) & 1 & 26.035 & 0.000 \\
X $_{4}$ (Status kawin KRT) & 1 & 7.415 & 0.006 \\
X $_{5}$ (Pendidikan KRT) & 4 & 197.930 & 0.000 \\
X $_{6}$ (Status pekerjaan KRT) & 1 & 20.499 & 0.000 \\
\hline Keterangan: nyata pada taraf nyata 5\% & &
\end{tabular}

Dugaan koefisien dan odds rationya disajikan pada Tabel 6. Jumlah ART berasosiasi positif dengan status anak bekerja. Peningkatan jumlah ART sebanyak 1 orang dapat meningkatkan risiko anak untuk bekerja sebesar $4.4 \%$. Hasil ini sangat mirip dengan sebelum dilakukan pemadanan. Demikian pula jika umur KRT bertambah 1 tahun, maka risiko anak untuk bekerja berkurang $0.8 \%$ atau menjadi 0.992 kali dibanding sebelumnya. Jika dilihat menurut status kawin KRT, anak dengan KRT berstatus kawin memiliki risiko lebih rendah ( $0.828 \mathrm{kali})$ untuk bekerja dibandingkan anak dengan KRT berstatus tidak kawin. Koefisien dan odds ratio setelah pemadanan untuk peubah status kawin KRT lebih kecil dibandingkan sebelum pemadanan.

Tabel 6: Dugaan koefisien dan Odds Ratio untuk setiap peubah penjelas dan kategorinya (setelah pemadanan)

\begin{tabular}{lcccc}
\hline \multicolumn{1}{c}{ Peubah } & Koefisien & $\begin{array}{c}\text { Galat } \\
\text { baku }\end{array}$ & $\begin{array}{c}\text { Odds } \\
\text { Ratio }\end{array}$ & $\begin{array}{c}\text { Selang } \\
\text { kepercayaan 95\% } \\
\text { bagi Odds Ratio }\end{array}$ \\
$\begin{array}{lcccc}\text { Jumlah ART } \\
\text { Jenis kelamin KRT: }\end{array}$ & 0.044 & 0.009 & 1.044 & $(1.027 ; 1.062)$ \\
$\quad$ Laki-laki & -0.077 & 0.072 & 0.925 & $(0.804 ; 1.065)$ \\
Umur KRT & -0.008 & 0.002 & 0.992 & $(0.989 ; 0.995)$ \\
$\begin{array}{l}\text { Status kawin KRT: } \\
\text { Kawin }\end{array}$ & -0.189 & 0.069 & 0.828 & $(0.723 ; 0.948)$ \\
$\begin{array}{l}\text { Pendidikan KRT: } \\
\text { SD/sederajat }\end{array}$ & -0.305 & 0.040 & 0.737 & $(0.682 ; 0.796)$ \\
$\quad$ SMP/sederajat & -0.420 & 0.047 & 0.657 & $(0.598 ; 0.721)$ \\
$\quad$ SMA/sederajat & -0.438 & 0.046 & 0.646 & $(0.590 ; 0.707)$ \\
$\quad \begin{array}{l}\text { Perguruan Tinggi } \\
\text { Status pekerjaan KRT: }\end{array}$ & -0.974 & 0.079 & 0.377 & $(0.323 ; 0.441)$ \\
$\quad \begin{array}{l}\text { Tidak bekerja/Pekerja } \\
\text { informal }\end{array}$ & 0.182 & 0.040 & 1.200 & $(1.109 ; 1.298)$ \\
\hline
\end{tabular}

Arah pengaruh peubah pendidikan KRT terhadap status anak bekerja konsisten dengan sebelum dilakukan pemadanan. Semakin tinggi pendidikan KRT, semakin kecil risiko anak untuk bekerja. Namun risiko yang diperoleh setelah pemadanan cenderung lebih tinggi dibandingkan sebelum pemadanan. Anak dengan KRT yang 
berpendidikan tamat SD/sederajat memiliki risiko 0.737 kali untuk bekerja dibandingkan anak dengan KRT yang tidak pernah sekolah/tidak tamat SD. Anak dengan KRT yang berpendidikan tamat SMP/sederajat memiliki risiko 0.657 kali untuk bekerja dibandingkan anak dengan KRT yang tidak pernah sekolah/tidak tamat SD. Selanjutnya, jika KRT berpendidikan tamat SMA/sederajat maka risiko anak untuk bekerja adalah 0.646 kali dibandingkan jika KRT tidak pernah sekolah/tidak tamat SD. Anak dengan KRT berpendidikan tamat Perguruan Tinggi memiliki risiko paling rendah untuk bekerja, yaitu sebesar 0.377 kali dibandingkan anak dengan KRT yang tidak pernah sekolah/tidak tamat SD. Selanjutnya, anak dengan KRT berstatus tidak bekerja/pekerja informal memiliki risiko lebih tinggi (1.2 kali) untuk bekerja dibandingkan anak dengan KRT berstatus pekerja formal.

Persamaan yang dihasilkan adalah sebagai berikut:

$$
\begin{aligned}
\ln \left(\frac{\hat{\pi}}{1-\hat{\pi}}\right)= & 0.044 x_{1}-0.077 D_{2}-0.008 x_{3}-0.189 D_{4}-0.305 D_{51}-0.420 D_{52} \\
& -0.438 D_{53}-0.974 D_{54}+0.182 D_{6}
\end{aligned}
$$

Perbandingan kinerja antara model regresi logistik baku dan model regresi logistik bersyarat disajikan dalam Tabel 7. Kriteria yang digunakan adalah Residual Deviance dan Akaike Information Criterion (AIC). Baik menggunakan kriteria Residual Deviance ataupun AIC, model regresi logistik bersyarat menghasilkan kinerja yang lebih baik dibandingkan model regresi logistik baku. Hal ini ditunjukkan oleh nilai Residual Deviance maupun AIC yang lebih kecil.

Tabel 7: Perbandingan kinerja antara model regresi logistik baku dan model regresi logistik bersyarat

\begin{tabular}{lcc}
\multicolumn{1}{c}{ Kriteria } & $\begin{array}{c}\text { Model regresi logistik } \\
\text { baku }\end{array}$ & $\begin{array}{c}\text { Model regresi logistik } \\
\text { bersyarat }\end{array}$ \\
\hline $\begin{array}{l}\text { Residual Deviance } \\
\text { Akaike Information }\end{array}$ & 63194.81 & 25948.50 \\
Criterion (AIC) & 63214.81 & 25970.50 \\
\hline
\end{tabular}

\section{Simpulan}

Analisis sebelum pemadanan menghasilkan kesimpulan yang berbeda dibandingkan dengan analisis setelah pemadanan. Kinerja analisis setelah pemadanan lebih baik dibandingkan dengan sebelum pemadanan. Pemadanan data telah mempertimbangkan adanya peubah pembaur (confounding variable), sehingga menampakkan pengaruh sebenarnya dari masing-masing peubah penjelas terhadap status anak bekerja. Status anak bekerja dipengaruhi oleh jumlah ART, umur KRT, status kawin KRT, tingkat pendidikan KRT, dan status pekerjaan KRT. Semakin banyak jumlah ART, semakin besar pula peluang anak untuk bekerja. Semakin bertambah umur KRT, semakin kecil peluang anak untuk bekerja. Selanjutnya, anak dengan KRT yang berstatus kawin memiliki risiko yang lebih rendah untuk bekerja dibandingkan anak dengan KRT yang berstatus tidak kawin. Semakin tinggi pendidikan KRT, semakin kecil risiko anak untuk bekerja. Terakhir, anak dengan KRT berstatus tidak bekerja/pekerja informal memiliki risiko yang lebih besar untuk bekerja dibandingkan anak dengan KRT berstatus pekerja formal. 


\section{Daftar Pustaka}

Agresti, A. (2002). Categorical Data Analysis (2nd ed). New York: Wiley-Interscience.

Agresti, A. (2007). An Introduction to Categorical Data Analysis (Second Edition). New Jersey: John Wiley \& Sons, Inc.

Azen, R., \& Walker, C. M. (2011). Categorical Data Analysis for the Behavioral and Social Sciences. https://doi.org/10.4324/9780203843611

[BPS] Badan Pusat Statistik. (2017). Pedoman Pencacah Survei Angkatan Kerja Nasional. Jakarta: BPS.

Haszelinna binti Abang Ali, D., \& Arabsheibani, G. R. (2016). Child Labour in Indonesia: Supply-Side Determinants. Economics and Finance in Indonesia, 62(3): 162-179. https://doi.org/10.7454/efi.v62i3.555

Hosmer, D. W., \& Lemeshow, S. (2000). Applied Logistic Regression (Second Edition). New York: Wiley-Interscience.

Ikawati. (2015). Faktor yang Mempengaruhi Anak Bekerja. Jurnal PKS, 14(2): 197210.

Iryani, B. S., \& Priyarsono, D. S. (2013). Eksploitasi terhadap Anak yang Bekerja di Indonesia. Jurnal Ekonomi dan Pembangunan Indonesia, 13(2): 177-195. https://doi.org/10.21002/jepi.v13i2.226

James, G., Witten, D., Hastie, T., \& Tibshirani, R. (2013). An Introduction to Statistical Learning with Applications in R. https://doi.org/10.1007/978-1-4614-7138-7

[Kemenaker] Kementerian Ketenagakerjaan Republik Indonesia. (2014). Peta Jalan (Roadmap) Menuju Indonesia Bebas Pekerja Anak Tahun 2022. Jakarta: Kementerian Ketenagakerjaan Republik Indonesia.

Kuo, C.-L., Duan, Y., \& Grady, J. (2018). Unconditional or Conditional Logistic Regression Model for Age-Matched Case-Control Data? Frontiers in Public Health, 6: 57. https://doi.org/10.3389/fpubh.2018.00057

Priyambada, A., Suryahadi, A., \& Sumarto, S. (2005). What Happened to Child Labor in Indonesia During the Economic Crisis: The Trade-off Between School and Work. SMERU Working Paper.

Thapa, S., Chhetry, D., \& Aryal, R. H. (1996). Poverty, Literacy and Child Labour in Nepal: A District-Level Analysis. Asia-Pacific Population Journal, 11(3): 3-14. https://doi.org/10.18356/7a364996-en

[UU] Undang-Undang Republik Indonesia Nomor 13 Tahun 2003 tentang Ketenagakerjaan. (2003).

[UU] Undang-Undang Republik Indonesia Nomor 20 Tahun 2003 tentang Sistem Pendidikan Nasional. (2003).

[UNICEF] United Nations Children's Fund. (2020). Situasi Anak odi Indonesia - Tren, Peluang, dan Tantangan dalam Memenuhi Hak-Hak Anak. Jakarta: UNICEF Indonesia.

Usman, H. (2002). Determinan dan Eksploitasi Pekerja Anak-anak di Indonesia (Analisis Data SUSENAS 2000 KOR). Universitas Indonesia, Depok.

Utama, R. S., \& Handayani, D. (2020). Pekerja Anak di Indonesia: Peran Penawaran dan Permintaan Ketenagakerjaan. Jurnal Ekonomi Kuantitatif Terapan, 13(1): 145-157. 